\title{
$\longrightarrow$ \\ Cheyenne River Sioux Traditions and Resistance to the Dakota Access Pipeline
}

\author{
Ryan Goeckner, Sean M. Daley, Jordyn Gunville, and Christine M. Daley
}

\begin{abstract}
The No Dakota Access Pipeline resistance movement provides a poignant example of the way in which cultural, spiritual, and oral traditions remain authoritative in the lives of American Indian peoples, specifically the Lakota people. Confronted with restrictions of their religious freedoms and of access to clean drinking water due to construction of the Dakota Access Pipeline (DAPL), members of Lakota communities engaged with traditions specific to their communities to inform and structure the No DAPL resistance movement. A series of interviews conducted on the Cheyenne River Sioux Nation with tribal members reveal that Lakota spiritual traditions have been integral to every aspect of the movement, including the motivations for, organization of, and understanding of the future of the movement.
\end{abstract}

KEYWORDS: activism, American Indian, Dakota Access Pipeline, Lakota, oral tradition, resistance, spirituality

Ho tunksila wakan tanka

Tateuye topa na ate wakan tanka

Namahonpo

Wiyohpeyata wakainyan oyate kin

Ahintonwanpo

Na Wiyohinyanpata sinte sapala oyate kin

Ahintonwanpo

$\mathrm{Na}$ itokagata wanbli oyate kin

Ahintonwanpo

Na maka ina na unci maka

Ahintonwanpo

$\mathrm{Na}$ wakatkiya na wakatkiya

Ahintonwanpo

Na hocoka wanbli gleska

Ahintonwanpo

Ho tunksila wakan tanka

Oyate oyasin unsiwicalapo na owicakiyapo

Nahan waci wicasa na waci winyan woipla tanka

Nahan oyate oyasin canku luta ogna mani owicakiyapo

Lucel wacin ho hecel le na oyate kin nipi kte

Mitakuye Oyasin
Grandfather, Great Spirit;

Four Winds, also Father, Great Spirit, hear me;

To the west, Thunder Being people, look upon me;

To the north, Buffalo people, look upon me; To the east, Black Tail Deer people, look upon me;

To the south, Eagle people, look upon me;

Mother Earth and Grandmother Earth, look upon me;

And upwards and upwards, look upon me;

To the center, Spotted Eagle, look upon me.

Grandfather, Great Spirit have pity on and help all the people;

Many thanks for the dance men and dance women;

And help the people that walk the Red Road. This I ask so that these people may live.

All My Relations

- Lakota prayer for public events and occasions 
The acrid smell of tear gas lingered as the sounds of bullets, gushing water cannons, and the piercing wail of the Long Range Acoustic Device cut through the cold North Dakota air. Individuals known as 'water protectors' were being attacked by law enforcement from five states, including the local Morton County Sheriff's Department. These water protectors had assembled to clear Highway 1806 in Morton County of a blockade of burned-out vehicles that had cut off travel to and from the Standing Rock Sioux Indian community. As they were met with the spray of water cannons in below-freezing temperatures, some protesters shouted at the militarized police force assembled to quell the protests, while other water protectors prayed.

The night of 20 November 2016 was the culmination of an eight-month struggle between American Indian and allied protesters and law enforcement, private mercenaries, and state and federal government officials over the construction of the Dakota Access Pipeline (DAPL) under Lake Oahe by the Texas-based fossil fuel infrastructure company Energy Transfer Partners. This was one of the most brutal exchanges between water protectors and the police force during the entire campaign against the crude oil pipeline's construction, resulting in numerous injuries, including the near amputation of one water protector's arm after taking a direct hit from a concussion grenade. ${ }^{1}$ People all over the United States, as well as members of the global community, watched in shock as guerrilla media groups broadcast video of water protectors being confronted by militarized police forces, National Guard troops, and private mercenaries as they protected their rights to clean water, tribal sovereignty, and religious expression. A confrontation of this nature between Natives and non-Natives had not been seen on American soil since the 1973 Wounded Knee Occupation on the Pine Ridge Indian Reservation in South Dakota.

Much of the initial coverage of the movement was led by online independent news outlets and the social media accounts of the protestors themselves. As noted by Jim Naureckas (2016a, 2016b, 2016c, 2017) of FAIR (Fairness and Accuracy in Reporting), inadequate coverage of this movement by the mainstream media pervaded until its later stages (see also Monet 2016). In addition to frequent failings to substantially or accurately represent the movement itself, mainstream media coverage tended to focus on narratives surrounding police brutality or corporate and governmental indifference toward ethnic minorities in the United States. ${ }^{2}$ These discourses placed the fight against DAPL in the same category as police responses to protest actions around the country, such as those surrounding the 2014 police killing of Michael Brown, a young African American, in Ferguson, Missouri, and the ongoing Flint water crisis in Flint, Michigan. In contrast, the centrality of water in Lakota spiritual tradition and practice-including knowledge of water's existence as "the first medicine" and its importance in ceremonies such as inipi (purification lodge), Wiwáyyang Wačhípi (Sun Dance), and haybléčheyapi (vision quest), evident through cries of "Mní Wičhóni" ("Water is Life," in Lakota)—-was the driving force of the movement for participants (Eagle 2017).

For many Lakota people involved with the DAPL protests, their cultural, spiritual, and oral traditions constituted the guiding force of what would become known as the No DAPL movement. In addition to making up a sizable portion of the protestors living in the camps, Lakota water protectors often brought with them an important motivation that lay behind the entire movement: Lakota cultural and spiritual practices and oral traditions. The media attention garnered by the protest movement was largely disinterested in or unaware of the more nuanced role that these cultural and spiritual practices and oral traditions played in the larger resistance movement; however, interviews with water protectors from the Cheyenne River Sioux Tribe revealed that they pervaded the movement in all aspects, including motivations for, organization of, and understanding of the future of the movement. 
The importance of water in Lakota life and spirituality cannot be overstated: water is valued not only as an obvious necessity of life, but also as a life-giving force. In fact, in Lakota tradition, $n i$ or niyá, is the breath that gives rise to life, or wóniya. It is ni that "imparts substance to a living form and contributes to its materialization" (Albers 2003: 291). Lakota elder George Sword makes this connection by stating: "The spirit of water is good for the $n i$ and will make it strong. Anything hot will make the spirit of the water free and it goes upward. It is like the $n i$, which can be seen with the breath on a cold day" (Walker [1980] 1991: 100). This notion is also reflected in some tellings of the White Buffalo Calf Woman narrative that describe her as walking "with visible breath." This is interpreted by some to indicate her membership in the Buffalo Nation, for they too are described as walking when moving as a herd on cold days when their breath visibly condenses (Albers 2003: 450).

\section{The Cheyenne River Sioux Tribe and No DAPL}

While most of the media coverage related to the No DAPL movement focused on the Standing Rock Sioux Tribe, the Cheyenne River Sioux Tribe (CRST) and its citizens were also involved with the protests from its inception. They, too, will be directly affected by eventual leaks and failures related to DAPL as the easternmost border of both reservations runs along Lake Oahe (Estes 2017: 117; Rome 2018: 68). Although the slogan "I stand with Standing Rock" became synonymous with the No DAPL movement, it left largely unstated the fundamental role in the resistance played by other Lakota communities, particularly Cheyenne River. Located in northcentral South Dakota, just south of the Standing Rock Sioux Tribe's reservation, the CRST reservation is the fourth-largest Indian reservation in the United States (Cheyenne River Sioux Tribe 2003). Established in 1889 when the Great Sioux Reservation was broken up by Congress, the CRST reservation encompasses approximately 4,300 square miles and is the home of four of the seven bands of the Lakota-the Mnicoujou, the Itazipco, the Oohenumpa, and the Siha Sapa. It currently has almost 16,000 enrolled tribal members, 70 percent of whom reside on the reservation (Bureau of Indian Affairs 2020). It also has one of the highest unemployment rates in Indian country-approximately 27.1 percent-and is considered one of the poorest communities in the United States with a 46.3 percent poverty rate and an average median family income of $\$ 18,156$ (Cheyenne River Reservation 2015).

Furthermore, as one Cheyenne River water protector explained, "the same water source affects [people] on Cheyenne River." ${ }^{3}$ Lake Oahe's presence as the easternmost boundary of the Cheyenne River reservation compelled CRST tribal citizens' participation in the movement. In the early 1940s, a series of economically devastating floods ravaged the Missouri River Valley, resulting in calls for Congress and the House Flood Control Committee to develop extensive flood management systems (Lawson 2009: 7) that led to the construction of the Oahe Dam impacting Cheyenne River Sioux lands. Ultimately, Congressional debate in 1944 resulted in the approval by President Franklin Delano Roosevelt of the Pick-Sloan Plan, which called for a total of 107 dams to be built along the Missouri (ibid.: 19). The Oahe Dam, constructed just north of Pierre, South Dakota, created Lake Oahe as we know it today. The flooding produced by its construction resulted in massive loss of tribal lands for both the Standing Rock and Cheyenne River Sioux Tribes. In total, Standing Rock lost nearly 56,000 acres, while Cheyenne River lost over 104,000 acres, requiring the relocation of almost one-third of the Tribe's population, as well as the Tribe's headquarters (ibid.: 47-48). Despite receiving financial compensation for this loss of land, the flooding had broader impacts that continue to impact the community today: loss of habitat for many herbs used in Lakota healing traditions, lack of access to significant spiritual 
sites, loss of prime grazing land for livestock, and the forced relocation of cemeteries to other parts of the reservation (ibid.: xvi, 49-51).

\section{CRST and the American Indian Health Research and Education Alliance}

We learned about issues related to the No DAPL movement, among many others, through our work with the American Indian Health Research and Education Alliance (AIHREA). Founded in 2006, AIHREA (n.d.) is a group of organizations whose mission is "to partner and collaborate with American Indian peoples, nations, communities, and organizations to improve the physical, mental, emotional, and spiritual well-being of American Indians throughout the United States through quality participatory research and educational programs." AIHREA members, including the authors, began CRST outreach efforts through educational activities, health disparity interventions, and community service projects during the summer of 2013 as part of the AIHREA summer internship program (Hale et al., forthcoming). This relationship continues through the involvement of CRST tribal members in ongoing outreach initiatives, research projects, and community advisory boards with AIHREA partners and in service trips to the CRST reservation (AIHREA, n.d.).

During our June 2016 trip to Cheyenne River, AIHREA team members became aware of the growing unrest related to DAPL's construction; this was one of our earliest introductions to these issues. Conversations with community members provided us with a glimpse into some of the more nuanced, yet crucial, motivations for CRST tribal members' involvement in this movement. Among them was the protection of Lakota cultural and religious traditions and sites in relation to DAPL's construction. As the movement grew through the late summer and fall of $2016,{ }^{4}$ community members began to raise concerns to us, and elsewhere, about the increasingly convoluted message being portrayed in the media as local, tribal control over the movement began to deteriorate. While the focus on water was central and unquestionably important, Lakota cultural and historical concerns connected to DAPL's construction had been pushed aside. As Walter Mengden (2017) mentions in his analysis of the No DAPL movement, this is often the case with Indigenous-led movements that encompass environmental concerns. As Indigenous movements grow, they are frequently co-opted by non-Indigenous groups, such as conservation and environmental groups, pushing tribal issues by the wayside and thus colonizing the movement's agenda as a whole (ibid.: 455; see also Waller 1999; Wolfley 1999).

During the 2017-2018 academic year, one of the authors, Ryan Goeckner, was completing his master's degree in religious studies and sought to highlight and further understand how resistance to DAPL was related to Lakota spiritual and oral traditions and motivated Lakota water protectors. ${ }^{5}$ Using our relationships with CRST members, alongside the body of scholarship related to Lakota spirituality, a series of ten, 30-60 minute interviews was conducted in three communities on the CRST reservation in March 2018 to attempt to answer these questions. Interviewees were enrolled CRST members aged 18-67 who were involved in the No DAPL movement. These key informants were selected through suggestions from our community contacts who identified participants in the No DAPL movement from CRST. Additional interviewees were identified through snowball sampling. All interviews were audio recorded and transcribed verbatim. Thematic statements were identified by the authors through inductive coding and a grounded theory approach to analysis (Charmaz 2001). Verbal informed consent was obtained by the interviewer, and standard human subjects protections protocols were followed. This project was approved by the University of Kansas Institutional Review Board and Cheyenne River Sioux Nation Tribal Chairman Harold Frazier. 


\section{Lakota Spirituality and the No DAPL Movement}

Unbeknownst to many, the earliest actions against the pipeline's construction were grounded in Lakota spirituality. According to CRST members, in the spring of 2016, at the request of former Standing Rock Tribal Chairman Dave Archambault II, a ride was organized to Cannonball, Standing Rock Sioux Nation, just north of what would become one of the many resistance camp sites. Rides-events in which groups of individuals ride horses to a set location of significance-are commonplace in contemporary Lakota activism. Other examples of this practice include annual rides to commemorate the Wounded Knee Massacre of 1890 and the Dakota $38+2$ Hanging of 1862 , but also more impromptu rides to exercise treaty rights on the 150th anniversary of the signing of the 1868 Fort Laramie Treaty, in protest of the continued incarceration of Leonard Peltier, and in solidarity with Kanaka Maoli kiai $i$ (Native Hawai ian Mauna Kea protectors) (Hopper 2018; Native News Online 2018; Taylor 2018).

Upon their arrival at what would become the site of Oceti Sakowin Camp, riders said "a really powerful prayer at that original site,... they smoked the pipe,... and sang some songs to protect the water and the people." Influential spiritual and political leaders from both communities were included and assisted in facilitation of these prayers. Prayer (wóchekiye) through the use of pipes is central to Lakota spiritual life and cannot be separated from the oral tradition describing the White Buffalo Calf Woman and her delivery of the White Buffalo Calf Pipe itself-the heart of Lakota spirituality (Paper 1988: 21-31; Powers [1975] 1982: 88; Steinmetz 1998: 104; Walker [1980] 1991: 83, 148).

Many formal Lakota ceremonies, as well as personal spiritual practices, revolve around praying with pipes, a tradition that began with the White Buffalo Calf Woman's arrival. Owing to its central importance for Lakota people today and in the past, many 'tellings' of this narrative exist in the literature, and countless others are extant in the oral tradition carried forward by Lakota people. ${ }^{7}$ While tellings differ slightly, the basic message of the story remains the same. Below, we provide one telling of this story, which encompasses the major points in the majority of tellings from the literature and in our knowledge of the oral tradition.

At some time in the distant past, after the Očhéthi Šakówin, or the Seven Council Fires, had met for their annual gathering, the bands went their separate ways. ${ }^{8}$ The Itazipco, one of the Thithunway bands, had traveled far looking for buffalo and other game but were unsuccessful. As a result, the council determined that a scouting party would be sent out and selected two young men for the task. After days of searching, the two men had found nothing. While planning their next move, they saw something approaching in the distance. As it got closer, they saw that it was a beautiful woman. One of the men lusted after her and approached her with bad intentions. The other cautioned him since he believed that she was wakhán. The lustful scout did not heed his companion's warning and approached anyway. As he advanced toward her he was engulfed in a large cloud of smoke. When the cloud dissipated, all that remained were his bones. The woman told the other hunter, now frightened, that he should return to his camp and tell his people to prepare a large lodge for her as she would be bringing something of great importance to them.

The scout returned to the camp and informed the elders about what had transpired. The people followed the woman's directions and awaited her arrival with great anticipation and excitement. The next morning, the woman arrived at daybreak and came into the camp. She brought with her a bundle wrapped in buffalo calf skin. When she arrived at the lodge they had constructed, she laid down the bundle, unwrapping it to reveal a pipe. She then instructed the people how to use the Pipe and informed them that if they lived according to her instructions, they would be prosperous and happy for all their days. She also explained 
that this Pipe, and the seven associated ceremonies she taught them, would allow them to communicate with Wakh́án Th́ánka. ${ }^{9}$ The smoke would carry their prayers, and she would petition Wakhán Thánka on their behalf.

After instructing them in the ways of the Pipe and the seven sacred ceremonies, she left the camp..$^{10}$ As she departed from the camp, she transformed into four different colored buffalo calves. The first was red, then black, then yellow, and finally white. Thus, she became known as the White Buffalo Calf Woman. ${ }^{11}$

The White Buffalo Calf Woman remains important to contemporary Lakota people for a variety of reasons, but in the context of resistance to DAPL, she is important for her passage of the White Buffalo Calf Pipe to the Lakota people. As previously noted, many formal Lakota ceremonies as well as personal spiritual practices revolve around praying with pipes. In bringing the Pipe to the Lakota people, the White Buffalo Calf Woman brought a new and integral method of communication with Waǩ́án Tȟ́nka.

Because of Euro-American interpretations of Lakota spirituality, including those of scholars who were/are heavily influenced (either personally or professionally) by Judeo-Christianity and Euro-American conceptions of religion, Lakota spirituality has often been mischaracterized and misunderstood. Furthermore, Lakota spirituality is arguably the most maligned of all American Indian spiritual traditions in the public consciousness (Aldred 2000; Bucko 1998: 104; Deloria 1992; Looking Horse 2003). Core concepts central to Lakota spirituality-specifically, Wakh̆́n Tȟ́nka, wakhán, and Mitákuye Oyás’in-are frequently misinterpreted and misrepresented as well. ${ }^{12}$

The concept Waǩ́án Th̆́nka has been greatly affected by misunderstandings of early ethnographers and Catholic missionaries, who used this term as a gloss for the Christian 'God', greatly simplifying the true nature of Wakh̆́n Th́ánka (Bucko 1998: 170-171; Powers [1975] 1982: 45; White Hat 2012: 175). These mischaracterizations continued well into the twentieth century through works of scholar-missionaries such as William Stolzman (1992) and Paul Steinmetz (1998) (see Bucko 1998: 104). Wakh̆́y is a concept that permeates all Lakota spiritual life. While it is often translated as 'holy' or 'transcendent', accounts by both Lakota individuals and scholars of Lakota spiritual traditions suggest a more nuanced meaning. They argue that its meaning is much closer to that of 'spiritual efficacy' or 'spiritual power' (DeMallie 1987: 28-30; Powers [1975] 1982: 45; White Hat 2012: 31, 84).

As it is frequently the essence to which prayers are directed, Wakh̆́n Thánka represents the collectivity of all things wakhán (Bucko 1998: 89, 126; DeMallie 1987: 30-31; Brown [1953] 1982: 5-6; Paper 1988: 45-46; Powers [1975] 1982: 54; Walker [1980] 1991: 31-32, 35; White Hat 2012: 175). Wakhán Th̆ánka is explained as having four aspects, each of which is comprised of four beings or classes of wakháy beings (Powers [1975] 1982: 170-171; Walker [1980] 1991: 127-128). These aspects are made up of a variety of beings including Inyay and Makhá and incorporating others, such as Wakinyay, or the thunder beings-a group of beings important in certain ritual contexts (see fig. 1) (Albers 2003: 288-289; Powers [1975] 1982: 54, 170171). Dakota ethnographer and linguist Ella Deloria states that the wakhán beings in Lakota tradition "were not grouped in a hierarchy," nor were they "anthropomorphized" and set into "Greek-like dramas" (Albers 2003: 289), as is often done by outsiders trying to understand Lakota spiritual traditions.

Not only are certain spiritual powers in the Lakota universe imbued with wakhán; important ceremonial objects such as pipes and ceremonies that include prayer are imbued with wakhán as well. The powers of the Lakota universe are not the only forces or beings understood to share this spiritual empowerment or waǩ̆áy. In fact, the collective nature of all things wakhán 


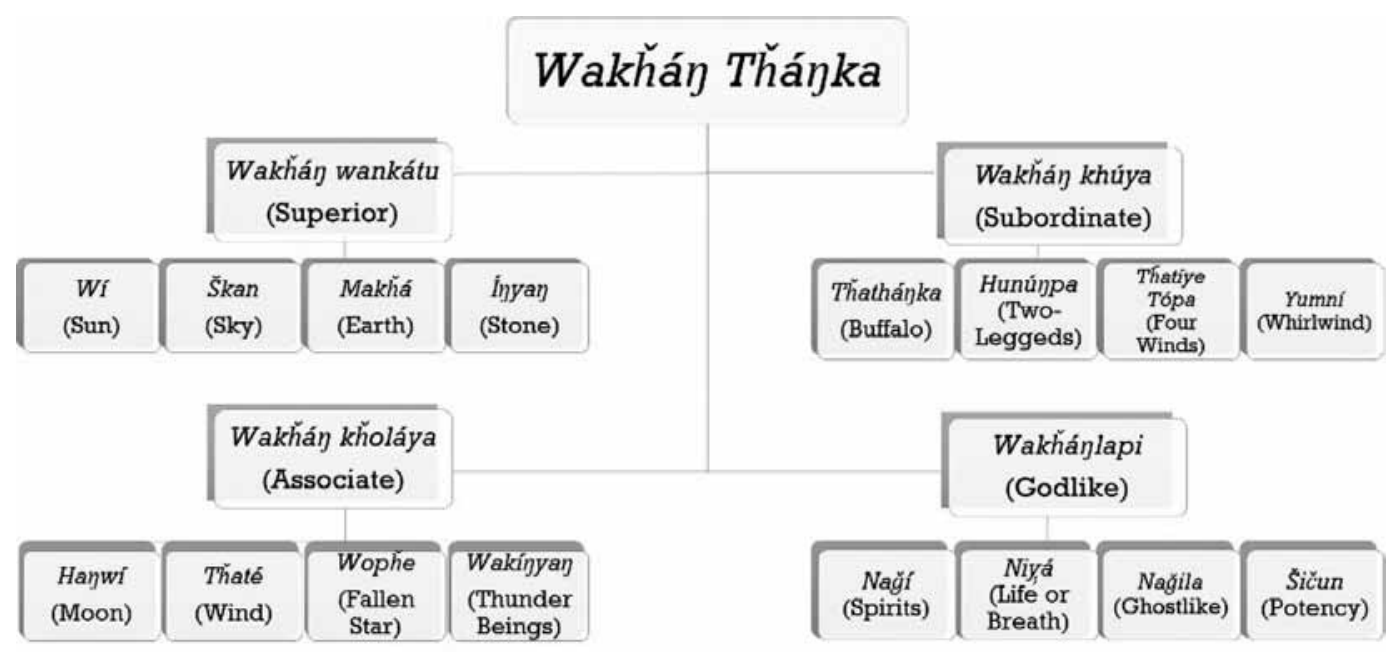

Figure 1: The different aspects of Wakhán Thánka. Adapted from Powers ([1975] 1982: 54, 170-171).

is understood by means of the concept. Throughout the No DAPL movement, the concept of wakhán and all things specifically associated with it were some of the most important aspects of Lakota spirituality in terms of water protectors' interpretations and engagement with the movement itself, as well as the guiding force of their motivations and actions.

Sičhánğu Lakota elder and retired instructor of Lakota Studies at Sinte Gleska University on the Rosebud Sioux Reservation, Albert White Hat states that wakháy is essential in establishing kin relationships, further undergirding the importance of Mitákuye Oyás'in (translated as "all of my relations" or "all my relatives") - a philosophical concept central to Lakota culture and spirituality (Albers 2003: 284; White Hat 2012: 84). Mitákuye Oyás’in expresses the connections Lakota peoples have to each other and all of creation, including mní, or water. White Hat (2012: xx) states: "Mitákuye Oyás'in ... is an oft-used phrase in our culture. Our philosophy and way of life are based on it." He goes on to say that Mitákuye Oyás'iy "describes our relationship with all of creation, that we are all relatives" (ibid.).

Whether it is stated explicitly or inferred, the philosophy of Mitákuye Oyás'in, or "all my relations," runs through every aspect of Lakota belief. It is an important foundational aspect of these traditions and undergirds the motivation for many Lakota community members' participation in No DAPL protests. ${ }^{13}$ Mitákuye Oyás'in is entrenched in the Lakota origin narrative, which in brief states:

In the beginning there was Inyay (stone), and in total darkness it began the creation of the world by bleeding itself. Out of its blood, Inyay first created Makhá, the earth, which it further divided into the land and Mní, the water. At the request of Makh́a, Anpétuwi, the sun, was created by Iyyay to bring light and warmth to the earth. Then, to provide balance to the light and warmth of the sun, Haywí, the moon, was created. (Albers 2003: 289, 295; White Hat 2012: 29-30)

Next, Inyan sought to provide the breath of life in the form of the wind, Thaté. Concerned that it was naked, Makhá, suggested that something be created to provide it a covering. After reaching an agreement with the other wakhán beings to provide for these creations, Inyan granted this request ushering into being all of the plants and other creatures on the earth. At this point, Inyay was very weak because it had been almost bled dry. The last creation was that 
of humanity. Creating women "to be like the earth, to give life and nourishment to all of her children," and men "to be like the universe, to provide nourishment and protection," Iyyay was completely dry and crumbled into many pieces which spread across the world. (Walker 1983: 194-197, 206-245; White Hat 2012: 29-30)

Even though the above is a truncated version of the narrative, the concept of Mitákuye Oyás'in can be easily understood. While the overarching purpose is to explain the way in which everything was created, it also illustrates how all of creation is related. From the "first relations ... the rocks" to the various animal nations including humanity, all things are related through the blood of Iyyay (White Hat 2012: 33). ${ }^{14}$ Moreover, all of creation is believed to care for one another, just as Maǩ́á is to provide for all of the things on its surface. All the beings on the earth are collectively known as the Wamákh̆aškay Oyáte (Animal Nations). These are further divided into other Oyátepi, or Nations, such as the Pte Oyáte (Buffalo Nation) and the Šúnkawakhán Oyáte (Horse Nation) (White Hat 2012: 32) ${ }^{15}$ Each of the beings whose existence is explained through this narrative is considered wakhán. Likewise, White Hat states that as "every creation comes from the blood of Iyyan ... every creation is wakhán," including water (ibid.: 31).

Lakota spirituality not only served as a catalyst for community-level involvement, but encouraged individual participation as well. For one Lakota young man, the importance of visionary experiences and dreams-a common theme in some Lakota ceremonies such as hajbléčheyapi, which is frequently enacted to learn one's purpose in life and to help prophesy the futurewas important for initiating his involvement in the movement (Powers [1975] 1982: 91; White Hat 2012: 75). He explained how, prior to the beginning of the protests, his mother had been given a prophetic dream. In this dream, her ancestors showed her the construction of the pipeline, including what the land looked like before and after its construction. This dream resonated strongly with him and provided much of the justification for his and his family members' involvement in resisting DAPL's construction. ${ }^{16}$ Similar experiences influenced youth involvement in the resistance movement. After establishing camps that would explode into the central hub of the movement as a whole, one young woman had a vision of "a day when, thanks to water pollution, there would be no water" (Elbein 2017). This vision was the catalyst for relay runs from their camp to Omaha, Nebraska and, eventually, Washington, DC, to deliver letters and petitions to the United States Army Corps of Engineers and to encourage increased practice of Lakota religious traditions among Lakota youth (ibid.). One run participant explained: “The whole point of us running was to get the kids to pray." 17 This example illustrates not only the influence of Lakota spirituality on individuals' participation, but also the importance of water in Lakota life.

From the early youth movement and the first ride up to what would become the site of the Oceti Sakowin Camp, Lakota spiritual traditions would continue to shape how the resistance organized its activities and understood the successes and failures of the movement. Spiritual leaders from the Cheyenne River Sioux community, under the advisement of wakhán beings through visionary experiences and responses to prayers, encouraged water protectors to practice a prayerful, peaceful protest. While occasional violent front-line actions involving law enforcement officials were a highly publicized part of the movement, they were not the norm, nor did they constitute the majority of interactions between water protectors and law enforcement. Lakota leaders and participants insisted that it was prayer that brought community members together and strengthened the movement. It was through prayer, one spiritual leader explained, that new communities were welcomed into the camps. He related that once in camp they "exchanged gifts, prayers, [and] songs" with the American Indian communities already present. ${ }^{18}$ Prayer and song were central to camp life as many participants described how the camps 
were always full of both. ${ }^{19}$ Whenever individuals discussed their experiences in camp, their descriptions included praying in some capacity or another. This included the exchange of songs with new activists from Tribal nations as they arrived in camp; the creation of tobacco ties, a common type of Lakota ceremonial offering; and "doing the last prayer [while they] waited for the [Morton County] Sheriff's Department to come in" and break up the camp. ${ }^{20}$

Prayer was not only present in the resistance camps; it was equally important on the front lines of protest actions. While recounting one of the most brutal exchanges between law enforcement and water protectors, described at the beginning of this article, one community member explained how, even in the chaos of what she described as a war zone atmosphere, "everybody was praying ... there were people singing, a lot of Indians and non-Indians praying together ... [when] they shot the water cannons." ${ }^{21}$ Another young man, who had participated in several of the runs organized by both Cheyenne River and Standing Rock Sioux youth to raise awareness about DAPL, described one protest action that aimed to wrest control of a known ancestral Lakota burial site from the hands of North Dakota law enforcement officials. At this site, referred to as Turtle Island, he was sprayed with mace while attempting to pray at the foot of the site.

Prayer was also important for individuals when water protectors were not able to be physically present in camp. When asked about the incident on Labor Day weekend in 2016, during which security personnel hired by Energy Transfer Partners released attack dogs on water protectors, one individual explained that even though he was not able to be in camp because of a prior commitment, he was able to pray in an effort to invoke wakh̆́n beings to intervene on behalf of the water protectors. The prayers by himself and others, he argued, continue to perpetuate the movement despite the pipeline's completion. This is because the work of these wakháy beings can still be seen in events such as the 2018 hurricanes in the Gulf of Mexico that damaged petroleum industry infrastructure. ${ }^{22}$ Likewise, after the camps were broken up by Morton County law enforcement officials, several individuals explained that prayer was, and continues to be, an important coping mechanism, as well as a way for water protectors to carry on resistance in diasporic camps around the Cheyenne River Sioux Tribe. ${ }^{23}$

It is clear that Lakota spirituality, through the mechanism of ongoing prayer, had a tangible presence in the resistance to DAPL. This practice was also seen as the source for most of the successes in the movement by community members. Just as the aftermath of hurricanes on petroleum infrastructure was seen as the work of Lakota spiritual forces, other parts of the movement were interpreted as being caused by the powerful nature of Lakota prayer. One Lakota civil rights activist explained that early on in the movement it appeared that the water protectors were winning the fight. He credited much of this success to the presence of traditional Lakota prayer, saying "to bring a drum to these [protest] actions... was huge. You could see the fear in state officials when they [heard] that drum beat and people singing ... that was huge." ${ }^{24}$ In many Indian cultures, including the Lakota, drums are considered culturally and spiritually significant, and are treated as such, with many Natives referring to a drum as a "Grandfather." Drums are usually treated with respect and reverence, in the same way a Roman Catholic would normally treat a crucifix. Drums and the accompanying songs are integral to many Lakota ceremonies; they are considered a form of prayer and a way to communicate with that which is wakhán.

This sentiment that the Lakota way of life was threatening to law enforcement officials was expressed by several community members. Many also measured this early success through the presence of Lakota spiritual forces in camp. One participant explained: "In the midst of all that there, the horse nation came, the buffalo nation came, the eagle nation came, and the Thoká Oyáte, the first people, the stones ... they all came there." 25 This statement refers directly to the Lakota creation narrative in which the world is created through the efforts of Inyay, a Lakota 
spirit being who remains on the earth as stones (Walker 1983: 194-197, 206-245; White Hat 2012: 29-30). It also illustrates the Lakota concept of Mitákuye Oyás’in, or "all of my relations," which describes how all of creation is connected in the Lakota worldview.

After the break-up of the camps in February 2016, CRST Chairman Harold Frazier opened the Tribe's powwow grounds in Eagle Butte, Cheyenne River Sioux Tribe, to water protectors who had nowhere else to go or who wanted to continue resisting DAPL's construction and the proposed Keystone XL Pipeline (Remle 2017). Since the establishment of this camp, however, fledgling camps all over the Cheyenne River Sioux Tribe have been founded, including camps in several communities around the reservation. The founders of these camps have a wide variety of ideas regarding what the next move should be for individuals wishing to continue the resistance movement. For example, one community member who remains engaged in the opposition to DAPL is focused on addressing post-traumatic stress disorder among water protectors, while another encourages sustainable living solutions among tribal citizens, highlighting the complementary environmental motivations for resistance.

According to one interviewee, the success of these camps hinges solely on the continuance of Lakota spirituality and prayerful protest, much like what was present in the resistance camps during the height of the movement. She explained that "after the fire was put out at the [Oceti Sakowin] camp, people lost that connectedness, they've lost that compassion ... during that crisis everybody came together as one. Now since that's been put out, you see more people that aren't in prayer ... They don't have a purpose, they've lost hope." ${ }^{26}$ She described parallels to the historic establishment of reservations that split many of the Lakota bands into separate communities and prevented the continuance of unity among the seven thióśpaye (bands) of the Lakota people. ${ }^{27}$

In the traditional Lakota camp organization, every band is situated around a central fire in a specific order (Walker 1982: 14-18). During the protest, the Oceti Sakowin Camp adhered to this structure and lit a sacred council fire in the center of these tipis. This participant explained that the campfire was tended day and night throughout the camp's existence, and that after water protectors began to establish disparate camps, they lost this connection and failed to establish this important connection to traditional Lakota life. ${ }^{28}$ The fire's presence in camp, which traditionally represented the unity of the Očhéthi Šakówin, highlighted resistance to the fragmentation of the Očhéthi Šakówin caused by the reservation system. Furthermore, a cultural center employee explained that this movement brought the disparate bands together and "made them stronger, it made them powerful like back in the day." ${ }^{29}$ The absence of this fire prevented members of these camps from establishing themselves as legitimate resistance camps and hindered them from fostering unity within the movement (Walker 1982: 17).

\section{Conclusion}

Just days after being inaugurated as the forty-fifth president of the United States, among a flurry of executive orders, Donald J. Trump advanced approvals for both the Dakota Access and Keystone XL Pipelines (Jones et al. 2017). Ignoring nearly a year of resistance, a fledgling administration, influenced by corporate interests, disregarded concerns by Native and non-Native water protectors from the United States and abroad about the construction of pipelines crossing important sources of fresh water in the Midwestern United States. Representing a continuation of colonialism perpetuated by the United States federal government, this disregard for the sovereignty of American Indian nations threw into sharp relief the lack of consideration for concerns expressed by these communities. 
While media coverage of the No DAPL movement was often distracted by scenes of water protectors facing off with law enforcement officials, the often not-so-subtle religious inspiration for the movement was frequently more important to water protectors. According to Lakota water protectors themselves, resistance to the construction of the Dakota Access Pipeline led by Lakota peoples was grounded in Lakota spiritual traditions. ${ }^{30}$ The movement itself was symbolically opened with prayer using the pipe, and such prayer would continue to be a central theme in protest actions and protest camp life-a tradition provided to Lakota people by the White Buffalo Calf Woman. Even in the camp diaspora on the Cheyenne River Sioux Nation, this prayer remains central for many water protectors. At the camp and on the front lines, prayer was being utilized in its many forms to connect with that which is wakhán to protect the Lakota relative mní. Often viewed as protests by outsiders, what was occurring was in fact prayers as well as wakhán acts.

Holistically, the movement itself was a prayer. Seemingly disparate pieces, much like Lakota spirituality as a whole, were interrelated and greater than the sum of their parts. Although many of those might not readily be categorized as prayers, such as the ride to establish and runs to publicize the movement, this designation becomes clearer when understood in the greater context of the Lakota philosophies of Mitákuye Oyás'in and wakhán. This prayerful movement, according to the water protectors we interviewed, provided the impetus for a reunification of the Očhéthi Šakówin and a reinvigoration of Lakota spirituality. Nevertheless, after the movement grew in visibility to the general public, it was co-opted by non-Lakotas who lacked an understanding of Lakota values and their overarching importance within the movement. In some ways, DAPL's construction and the subsequent breakdown of the resistance camps can be understood as a modern-day recurrence of the colonization of Lakota lands and suppression of their traditional lifeways. Just as traditional Lakota camp life was disrupted by the establishment of the reservation system, without prayer and other cultural, social, and religious structures, the movement floundered, struggling to find direction and purpose.

Lakota spirituality's importance to the No DAPL movement in terms of organization and strategies for resistance notwithstanding, it is important to note that stereotypical assessments of American Indians' connection to and protection of the earth is a vast oversimplification of the complexities of contemporary life in American Indian communities around the country. The spiritual inspirations behind the No DAPL movement should not overshadow the practical political and health-related issues that faced many Lakota water protectors. Concerns over both the sovereignty of Tribal nations and the protection of access to clean drinking water for community members constituted the many ways in which resistance took shape. Through their cultural, oral, and spiritual traditions, Lakota community members organized and defined the No DAPL movement. A deeper understanding of this resistance movement illuminates the importance of these traditions in contemporary Lakota life.

\section{ACKNOWLEDGMENTS}

The authors would like to thank the citizens of the Cheyenne River Sioux Nation for their endless hospitality and willingness to share their stories with us. This project is dedicated to all water protectors in Lakota communities and elsewhere fighting for access to clean drinking water and the free expression of American Indian religious traditions. 
RYAN GOECKNER, MA, is a doctoral student at The Ohio State University and a research scientist with the Institute for Indigenous Studies in the College of Health at Lehigh University. His research concentrations include American Indian religious traditions, Indigenous activism, and ethnographic methods. For his dissertation research, he will examine the role that participation in Lakota memorial and resistance rides, such as the Chief Big Foot Memorial Ride, plays in contemporary Lakota identity formation. He also works with the American Indian Health Research and Education Alliance on community-based participatory research projects that focus on American Indian health and wellness. E-mail: goeckner.1@buckeyemail.osu.edu

SEAN M. DALEY, PhD, MA, is a Professor of Practice and Co-director of the Institute for Indigenous Studies in the College of Health at Lehigh University in Bethlehem, Pennsylvania. He is an applied cultural anthropologist/ethnographer with expertise in American Indian Studies, community-based participatory research, and cultural tailoring. He has worked with Native peoples since 1995 in Arizona, Connecticut, Kansas, Montana, New Mexico, and South Dakota, as well several other states. He has conducted, with numerous American Indian communities, multiple ethnographic studies focused on health and wellness, law and policy, identity, education, and the environment. E-mail: smdaley@lehigh.edu

JORDYN GUNVILLE, MPH, is an enrolled member of the Cheyenne River Sioux Tribe and a doctoral student in the Department of Health Policy and Management at the University of Kansas Medical Center. She is also a research scientist with the Institute for Indigenous Studies in the College of Health at Lehigh University in Bethlehem, Pennsylvania. Her research efforts focus on maternal child health, smoking cessation, and breast cancer in American Indian communities. Since 2011, she has worked on a variety of research projects centered on American Indian ethnic identity, smoking cessation, primary care screenings, and breast cancer. E-mail: jog320@lehigh.edu

CHRISTINE M. DALEY, PhD, MA, SM, is a Professor and Co-director of the Institute for Indigenous Studies in the College of Health at Lehigh University in Bethlehem, Pennsylvania. She is an applied medical anthropologist with expertise in community-based participatory research and mixed methods. Her work with Native communities around the United States for over 20 years has focused on reducing health disparities through prevention research and culturally tailored interventions. E-mail: cmdaley@lehigh.edu 


\section{NOTES}

The Lakota prayer on the title page of this article is from a Lakota language audiocassette series, Conversational Lakota, published in 1991 by B.E.A.R., http://www.worldcat.org/oclc/317441904, and its accompanying lesson books. This specific prayer is from lesson VI.

1. The events described were largely ignored by mainstream media sources apart from limited coverage of the conflict between the citizens of the Standing Rock Sioux Indian community and Dakota Access. However, they were covered by a variety of alternative media sources and Facebook livestreams from the protest itself. For example, see Indian Country Today (2016); Monet (2016); Naureckas (2016a, 2016b, 2016c); RedactedTonight (2016a, 2016b); and Sacred Stone Camp (2016).

2. For a full overview of Democracy Now!'s coverage of the Dakota Access Pipeline resistance movement, see Democracy Now! (2018).

3. Interview with Cheyenne River Sioux tribal employee, 2018, edited by Ryan Goeckner.

4. For an overview of the key moments in the No DAPL movement, see Estes (2019: 25-65).

5. This article includes a small portion of research conducted for Goeckner's MA in religious studies. The interviews referenced here were submitted to the University of Kansas Institutional Review Board and approved on 25 October 2017. On 7 March 2018, Cheyenne River Sioux Nation Tribal Chairman Harold Frazier granted permission to conduct interviews in this community as a part of Goeckner's project. This complete work can be found in Goeckner (2018).

6. Interview with Cheyenne River Sioux tribal employee, 2018, edited by Ryan Goeckner.

7. The use of the term 'tellings' is a conscious decision. Much like Ramanujan (1991: 24) in his study of the multiplicity in the Ramayana tradition in South Asia, the use of 'tellings', instead of 'versions', avoids the assumption that these accounts all stem from one original, thus undermining the authority of the individual texts by implying that they derived from one urtext.

8. Očhéthi Šakówin denotes the traditional nomenclature referring to the Lakota-, Nakota-, and Dakotaspeaking peoples collectively. For more on the use of this terminology, see Powers ([1975] 1982: 11-14).

9. When referring to the Pipe brought by the White Buffalo Calf Woman, we will use the treatment as seen here. Other, similar Lakota terms are treated in this way.

10. These seven ceremonies include Inípi (purification or sweat lodge), Haybléchyapi (crying for vision), Wiwányang Wačhípi (sun dance), Hunkálowaypi (making of relatives), Išnáthi Awhíčhalowaypi (female puberty ceremony), Tȟ́pa Wankáyeyapi (throwing of the ball), and Wanáği Yuhápi (soul keeping). For more on each of these ceremonies, see Brown ([1953] 1982), Powers (1982: 86-103), and White Hat (2012: 74-94, 111-129).

11. Tellings consulted for this summary include Black Bear (1996: 1-2); Buechel (1998: 408-413); Davis (1944: 122-129); Demallie (1984: 283-285); Densmore (1916); Dorsey (1906); Brown ([1953] 1982: 3-9); Erdoes and Ortiz (1984: 47-52); Kelly (2007); KnewWays (2010); Lame Deer and Erdoes (1972: 251-255); Loder and Deloria (1967); Looking Horse (1987: 67-69); Matson (2016: 13-14); Neihardt ([1932] 2014: 1-3, 291-296); Smith (1970: 87-88; 1994: 1-4); St. Pierre and Long Soldier (1995: 39-41); and Walker ([1980] 1991: 109-112, 148-150).

12. In addition to problematic representations by Stolzman (1992) and Steinmetz (1998), other scholarship and popular literature pertaining to Lakota spirituality contribute to these misunderstandings. For instance, the validity and authenticity of John G. Neihardt's ([1932] 2014) Black Elk Speaks, arguably the most widely read book on Lakota spirituality, continue to be called into question by Lakota and non-Lakota scholars alike (DeMallie 1984: 32; White Hat 2012: 76-77). Furthermore, New Age authors (e.g., the late Sun Bear) capitalize on continued misrepresentations of Lakota spirituality that are popular among the general public (Aldred 2000:337-338). But, thankfully, reliable scholarship on Lakota spirituality does exist through works such as Albert White Hat's (2012) Life's Journey-Zuya, as well as William Powers's (1977) Oglala Religion and Raymond DeMallie and Douglas Parks's (1987) Sioux Indian Religion.

13. See White Hat (2012: 16-17) for a comprehensive discussion of this concept.

14. Interview with No DAPL run participant, 2018, edited by Ryan Goeckner. 
15. Interview with Cheyenne River Sioux Tribe spiritual leader, 2018, edited by Ryan Goeckner.

16. Interview with brother of camp cook, 2018, edited by Ryan Goeckner. The content of dreams and visions among Lakota people is often discussed only under certain circumstances. This explains the lack of detail in this account as it was not appropriate for this interviewee to share finer details of his mother's experience with the author.

17. Interview with No DAPL run participant, 2018, edited by Ryan Goeckner.

18. Interview with Cheyenne River Sioux Tribe spiritual leader, 2018, edited by Ryan Goeckner.

19. Interviews with a Cheyenne River Sioux Tribe spiritual leader, the sister of a camp cook, a Cheyenne River Sioux tribal employee, a cultural center employee, and a Lakota water protector, 2018, edited by Ryan Goeckner 2018.

20. Interview with brother of camp cook, 2018, edited by Ryan Goeckner.

21. Interview with Cheyenne River Sioux tribal employee, 2018, edited by Ryan Goeckner.

22. Interview with Cheyenne River Sioux Tribe spiritual leader, 2018, edited by Ryan Goeckner.

23. Interviews with a Cheyenne River Sioux tribal employee, a No DAPL run participant, the parent of a No DAPL run participant, a Cheyenne River Sioux Tribe spiritual leader, and a Cheyenne River Sioux Tribe veteran, 2018, edited by Ryan Goeckner.

24. Interview with Lakota civil rights activist, 2018, edited by Ryan Goeckner.

25. Interview with Cheyenne River Sioux Tribe spiritual leader, 2018, edited by Ryan Goeckner.

26. Interview with Cheyenne River Sioux tribal employee, 2018, edited by Ryan Goeckner.

27. Ibid.

28. Ibid.

29. Interview with cultural center employee, 2018, edited by Ryan Goeckner.

30. Interviews with Lakota water protectors, 2018, edited by Ryan Goeckner.

\section{REFERENCES}

AIHREA (American Indian Health Research and Education Alliance). n.d. "Who We Are." http://aihrea. org/who-we-are.html (accessed 30 October 2020).

Albers, Patricia C. 2003. The Home of the Bison: An Ethnographic and Ethnohistorical Study of Traditional Cultural Affiliations to Wind Cave National Park. Vol. 1. Hot Springs, SD: US National Park Service and the Department of American Indian Studies, University of Minnesota.

Aldred, Lisa. 2000. "Plastic Shamans and Astroturf Sun Dances: New Age Commercialization of Native American Spirituality." American Indian Quarterly 24 (3): 329-352.

Black Bear, G. 1996. "VOICES: White Buffalo Calf Woman Legend Needs to Be Clarified." Indian Country Today, 18 November. http://proxy.lib.ohio-state.edu/login?url=https://www-proquest-com.proxy. lib.ohio-state.edu/docview/362705470?accountid=9783.

Brown, Joseph Epes, ed. (1953) 1982. The Gift of the Sacred Pipe: Based on Black Elk's Account of the Seven Rites of the Oglala Sioux. Norman: University of Oklahoma Press.

Bucko, Raymond A. 1998. The Lakota Ritual of the Sweat Lodge: History and Contemporary Practice. Lincoln: University of Nebraska Press.

Buechel, Eugene. 1998. Lakota Tales \& Texts. Trans. Paul Manhart. Chamberlain, SD: Tipi Press.

Bureau of Indian Affairs. 2020. "Cheyenne River Agency." https://www.bia.gov/regional-offices/ great-plains/south-dakota/cheyenne-river-agency.

Champagne, Duane, ed. 1999. Contemporary Native American Cultural Issues. Walnut Creek, CA: AltaMira Press.

Charmaz, Kathy. 2001. "The Logic of Grounded Theory." In Contemporary Field Research: Perspectives and Formulations, ed. Robert M. Emerson, 335-352. Long Grove, IL: Waveland Press.

Cheyenne River Reservation. 2015. "A Snapshot of the Cheyenne River Sioux Reservation: Income and Employment." https://web.archive.org/web/20170817133620/http://crtribalventures.org/ cheyenne-river-reservation/. 
Cheyenne River Sioux Tribe. 2003. "Cheyenne River Sioux History." http://sioux.org/cheyenne-riversioux-history.html.

Davis, Lawrence J. 1944. “The Socio-cultural Changes in the Cheyenne River Sioux Indians as a Result of Contact with White Civilization." MA thesis, University of Southern California.

Deloria, Vine, Jr. 1992. "Is Religion Possible? An Evaluation of Present Efforts to Revive Traditional Tribal Religions." Wicazo Sa Review 8 (1): 35-39.

DeMallie, Raymond J., ed. 1984. The Sixth Grandfather: Black Elk's Teachings Given to John G. Neihardt. Lincoln: University of Nebraska Press.

DeMallie, Raymond J. 1987. “Lakota Belief and Ritual in the Nineteenth Century." In DeMallie and Parks 1987, 25-44.

DeMallie, Raymond J., and Douglas R. Parks, eds. 1987. Sioux Indian Religion: Tradition and Innovation. Norman: University of Oklahoma Press.

Democracy Now! 2018. "Dakota Access Pipeline." https://www.democracynow.org/topics/dakota_access.

Densmore, Frances. 1916. Teton Sioux Music. Bulletin/Smithsonian Institution, Bureau of American Ethnology no. 61 (1918). G.P.O, 1901. https://library.si.edu/digital-library/book/bulletin611918smit.

Dorsey, George A. 1906. "Legend of the Teton Sioux Medicine Pipe." Journal of American Folklore 19 (75): 326-329. https://www.jstor.org/stable/534439?seq=1\#metadata_info_tab_contents.

Eagle, Jon, Sr. 2017. "Turbulent Water: The Dakota Access Pipeline and Traditional Cultural Landscapes." Forum Journal 31 (3): 61-68.

Elbein, Saul. 2017. “The Youth Group That Launched a Movement at Standing Rock.” New York Times, 31 January. https://www.nytimes.com/2017/01/31/magazine/the-youth-group-that-launched-amovement-at-standing-rock.html.

Erdoes, Richard, and Alfonso Ortiz, eds. 1984. American Indian Myths and Legends. New York: Pantheon Books.

Estes, Nick. 2017. “Fighting for Our Lives: \#NoDAPL in Historical Context.” Wicazo Sa Review 32 (2): 115-122. doi:10.5749/wicazosareview.32.2.0115.

Estes, Nick. 2019. Our History Is the Future: Standing Rock versus the Dakota Access Pipeline, and the Long Tradition of Indigenous Resistance. New York: Verso.

Goeckner, Ryan. 2018. “'These Type of Sites Are Really Hard to Find': Lakota Oral Tradition and Resistance against the Dakota Access Pipeline." MA thesis, University of Kansas.

Hale, Jason, Jordyn Gunville, Ryan Goeckner, Charley Lewis, Sean Daley, Christine Daley, and Won Choi. Forthcoming. "A Community-Based Participatory Research Training Program for American Indian Students." Journal of Racial and Ethnic Health Disparities.

Hopper, Frank. 2018. "Leonard Peltier Freedom Riders Reach White House after 1,500 Mile Spirit Ride." Indian Country Today Media Network, 6 November. https://newsmaven.io/indiancountrytoday/news/ leonard-peltier-freedom-riders-reach-white-house-after-1-500-mile-spirit-ride-aZX2UJuTHEqGHBvOoApb4w/.

Indian Country Today. 2011. "Annual Chief Big Foot Memorial Ride to Wounded Knee Concludes." 29 December. https://indiancountrytoday.com/archive/annual-chief-big-foot-memorial-ride-towounded-knee-concludes-bc6Tm6CxQ0qoMS-C7trDqA\#: :text=There\%2C\%20the\%20riders\%20 offered\%20prayers,massacred\%20by\%20the\%207th\%20Cavalry.

Indian Country Today. 2016. "Amnesty International USA Derides ND for Subfreezing Water Onslaught.” 21 November. https://indiancountrymedianetwork.com/news/native-news/amnestyinternational-usa-derides-nd-for-subfreezing-water-onslaught/ (accessed 23 April 2017).

Jones, Athena, Jeremy Diamond, and Gregory Krieg. 2017. “Trump Advances Controversial Oil Pipelines with Executive Action.” CNN, 24 January. https://www.cnn.com/2017/01/24/politics/trumpkeystone-xl-dakota-access-pipelines-executive-actions/index.html.

Kelly, Robert. 2007. “The Story of the White Buffalo Calf Woman.” YouTube, posted 26 June. https:// www.youtube.com/watch? $v=e z N K g R b n V P Y$.

KnewWays. 2010. "Chief Arvol Looking Horse Speaks of White Buffalo Prophecy." YouTube, posted 27 August, modified in 2016. https://www.youtube.com/watch?v=PHqVdZmpRgI. 
Lame Deer, John (Fire), and Richard Erdoes. 1972. Lame Deer, Seeker of Visions: The Life of a Sioux Medicine Man. New York: Simon \& Schuster.

Lawson, Michael L. 2009. Dammed Indians Revisited: The Continuing History of the Pick-Sloan Plan and the Missouri River Sioux. Pierre, SD: South Dakota State Historical Society Press.

Loder, Richard R., and Ella C. Deloria. 1967. “The Sacred Calf Pipe." University of South Dakota Bulletin 18: 4-6. https://explore.digitalsd.org/digital/collection/univ_arc/id/215.

Looking Horse, Arvol. 1987. “The Sacred Pipe in Modern Life.” In DeMallie and Parks 1987, 67-74.

Looking Horse, Arvol. 2003. "Looking Horse Proclamation on the Protection of Ceremonies.” Indian Country Today, 25 April. https://indiancountrytoday.com/archive/ looking-horse-proclamation-on-the-protection-of-ceremonies-2IW86M5KiUm71NiBOX0PlA.

Matson, William B. 2016. Crazy Horse: The Lakota Warrior's Life and Legacy. Layton, UT: Gibbs Smith.

Mengden, Walter H., IV. 2017. "Indigenous People, Human Rights, and Consultation: The Dakota Access Pipeline." American Indian Law Review 41 (2): 441-466.

Monet, Jenni. 2016. "Mainstream Media MIA as DAPL Action Is Met with Water Cannons and Mace." 22 November. https://popularresistance.org/ mainstream-media-mia-as-dapl-action-is-met-with-water-cannons-and-mace/.

Native News Online. 2018. "Cheyenne River Sioux Tribe Making Plans to Journey to the 150th Anniversary of the Signing of the Fort Laramie Treaty of 1868." https://nativenewsonline.net/currents/cheyenne-river-sioux-tribe-making-plans-journey-150th-anniversary-signing-fort-laramie-treaty-1868/ (accessed on 3 March 2018).

Naureckas, Jim. 2016a. "Dakota Access Blackout Continues on ABC, NBC News." Fairness \& Accuracy in Reporting, 22 September. http://fair.org/home/ dakota-access-blackout-continues-on-abc-nbc-news/.

Naureckas, Jim. 2016b. "48 Words at 4 AM Is All Network News Has to Say about Pipeline Protests." Fairness \& Accuracy in Reporting, 7 September. http://fair.org/ home/48-words-at-4-am-is-all-network-news-has-to-say-about-pipeline-protests/.

Naureckas, Jim. 2016c. "Nothing to See Here' Headlines Conceal Police Violence at Dakota Access." Fairness \& Accuracy in Reporting, 22 November. http://fair.org/home/ nothing-to-see-here-headlines-conceal-police-violence-at-dakota-access/.

Naureckas, Jim. 2017. "Hiding DAPL Violence Behind 'Nothing to See Here' Headlines." Fairness \& Accuracy in Reporting, 1 January. https://fair.org/home/ hiding-dapl-violence-behind-nothing-to-see-here-headlines/.

Neihardt, John G. (1932) 2014. Black Elk Speaks. Ed. Philip Joseph Deloria and Raymond J. DeMallie. Lincoln: University of Nebraska Press.

Paper, Jordan D. 1988. Offering Smoke: The Sacred Pipe and Native American Religion. Moscow: University of Idaho Press.

Powers, William K. (1975) 1982. Oglala Religion. Lincoln: University of Nebraska Press.

Ramanujan, A. K. 1991. "Three Hundred Rāmāyaṇas: Five Examples and Three Thoughts on Translation." In Many Rāmāyanas: The Diversity of a Narrative Tradition in South Asia, ed. Paula Richman, 22-49. Berkeley: University of California Press.

RedactedTonight. 2016a. “400 DAPL Protesters 'Trapped on Bridge’ as Police Fire Tear Gas, Water Cannon.” 21 November. https://www.rt.com/usa/367592-dapl-protest-bridge-teargas/.

RedactedTonight. 2016b. "Police Threw Grenade at DAPL Protesters-Father of Activist Who Faces Amputation.” 22 November. https://www.rt.com/usa/367771-dapl-protester-arm-amputation/.

Remle, Matt. 2017. "Joye Braun on the Wakpa Waste Camp and the Fight to Stop the Keystone XL Pipeline." Last Real Indians. https://lastrealindians.com/joye-braun-on-the-wakpa-waste-camp-and-thefight-to-stop-the-keystone-xl-pipeline/ (accessed 17 November 2017).

Rome, Andrew. 2018. "Black Snake on the Periphery: The Dakota Access Pipeline and Tribal Jurisdictional Sovereignty." North Dakota Law Review 93 (1): 57-86.

Sacred Stone Camp. 2016. "Water Cannons Fired at Water Protectors in Freezing Temperatures Injure Hundreds." 21 November. http://sacredstonecamp.org/blog/2016/11/21/ water-cannons-fired-at-water-protectors-in-freezing-temperatures-injure-hundreds. 
Smith, J. L. 1970. “The Sacred Calf Pipe Bundle: Its Effect on the Present Teton Dakota." Plains Anthropologist 15 (48): 87-93.

Smith, J. L. 1994. A Short History of the Sacred Calf Pipe of the Teton Dakota. Kendall Park, NJ: Lakota Books.

St. Pierre, Mark, and Tilda Long Soldier. 1995. Walking in the Sacred Manner: Healers, Dreamers, and Pipe Carriers-Medicine Women of the Plains Indians. New York: Simon \& Schuster.

Steinmetz, Paul B. 1998. The Sacred Pipe: An Archetypal Theology. Syracuse, NY: Syracuse University Press.

Stolzman, William. 1992. The Pipe and Christ: A Christian-Sioux Dialogue. Chamberlain, SD: Tipi Press.

Taylor, Alan. 2018. "A 400-Mile Ride to Mark 150 Years of the Fort Laramie Peace Treaty." Atlantic, 2 August. https://www.theatlantic.com/ photo/2018/08/a-400-mile-ride-to-mark-150-years-of-the-fort-laramie-peace-treaty/566654/.

Walker, James R. (1980) 1991. Lakota Belief and Ritual. Ed. Raymond J. DeMallie and Elaine A. Jahner. Lincoln: University of Nebraska Press.

Walker, James R. 1982. Lakota Society. Ed. Raymond J. DeMallie. Lincoln: University of Nebraska Press.

Walker, James R. 1983. Lakota Myth. Ed. Elaine Jahner. Lincoln: University of Nebraska Press.

Waller, David. 1999. "Friendly Fire: When Environmentalists Dehumanize American Indians." In Champagne 1999, 277-292.

White Hat, Albert, Sr. 2012. Life's Journey-Zuya: Oral Teachings from Rosebud. Ed. John Cunningham. Salt Lake City: Univesity of Utah Press.

Wolfley, Jeanette. 1999. “Ecological Risk Assessment and Management: Their Failure to Value Indigenous Traditional Ecological Knowledge and Protect Tribal Homelands.” In Champagne 1999, 293-306. 